\title{
The Impact of Innovation Strategy on the Financial, Social and Environmental Performance
}

\author{
Hamid Saremi, Masoud Mahmoudi, Mojtaba Soltaninezhad, Mohammad Hosseinpour
}

\begin{abstract}
The core purpose of this study is to investigate the effect of innovation strategy on financial, social and environmental performance of companies listed on the Tehran Stock Exchange (TSE). The information used is from 129 companies listed on TSE in different industries between 2011 and 2018 (1032 observations). In order to analyze the data, a multivariate regression test was used. The results showed a positive and significant relationship between innovation strategy on financial performance and environmental performance. Also, the relationship between innovation strategy and social performance has a positive but insignificant. Innovation tools are also among the few management tools that can have a positive impact on both financial performance and the company's environmental performance. In this research, an attempt has been made to look at the idea of innovation from a financial point of view, and its results in the long run indicate the right choice of management to invest in the company's research and development unit.
\end{abstract}

Keywords: Innovation Strategy, Financial Performance, Social Performance, Environmental Performance.

\section{INTRODUCTION}

Innovation, further known in finance as investment in research and development (R\&D), has been accepted as a member of a company's family for the past 200 years or so, and over time companies have found that they need a key innovation to survive. Geographically, the concept of innovation in different parts of the world has a general meaning called creativity, which dates back to the beginning of human evolution. For the past 200 years, when innovation has entered the formal business world, the concept of financial class innovation has been recognized among investors and managers. This concept was developed by companies and eventually became a sustainable research and development (R\&D) unit. A circle whose main task is to

Manuscript received on 05 April 2021 | Revised Manuscript received on 25 April 2021 | Manuscript Accepted on 15 May 2021 | Manuscript published on 30 May 2021.

* Correspondence Author

Dr. Hamid Saremi*, Financial Engineering department, Asrar institute of higher education, Mashhad, Iran. Email: hadi_sarem@yahoo.com

Masoud Mahmoudi, Accounting department, Shandiz institute of higher education, Mashhad, Iran.

Mojtaba Soltaninezhad, Accounting department, Asrar institute of higher education, Mashhad, Iran.

Mohammad Hosseinpour, Ph.D student Accounting department, Islamic Azad University, Qaenat, Iran.

(C) The Authors. Published by Lattice Science Publication (LSP). This is an open access article under the CC-BY-NC-ND license (http://creativecommons.org/licenses/by-nc-nd/4.0/) create a new product and today it plays a role as an effective unit in the financial, social and even environmental fields in companies. The literature shows that R\&D are influential on a company's performance. In these research, the effect of R\&D on profitability, productivity, income and sales at the level of enterprise activity has been studied (Schroll \& Mild, 2011; Westburg and Wieshamar, 2012; Brjeston Loften, 2012). In other studies, the impact of R\&D spending on GDP, economic growth, and the overall productivity of factors of production have been examined at the macro level (Wright and Braddle and Van Verinen, 1999; Yol Kio, 2002; Kim and bay, 2003).

Since the early 1940s, economists have shown that inventions and advances in technology are the driving force behind economic growth, and that research and development is the way to go (Schocler, 1993). This relationship was further strengthened when the rapid decline in the cost of research and the development of the private sector in the United States led to the deterioration of the 1970s and 1980s. The rate of investment on R\&D declined during the 1980s, and social and private sector returns on research and development were significantly offset (Hall, 1993). Since then, a large part of the research has found acceptable explanations for this. Eventually, the overall picture led to the existence of research and development costs (Grilichs, 1983). Today, the prevailing view is that securing research and development credits is a very important factor in strengthening innovation. The general hypothesis is that more innovations will lead to more patents, and a decrease in the number of patents is a sign of declining innovative activity and a sign of productivity slowing down due to the wear and tear of the invention, as happened in the 1970s. Registered inventions are often considered the end product of $R \& D$ investment. Any action that affects the efficiency of research and development will affect the patents registered. Grilichs (1987) showed that patents are a constant measure of a company's performance.

\section{THEORETICAL FRAMEWORK AND LITERATURE REVIEW}

\section{A. Innovation Strategy and Financial Performance}

In the last two decades, events such as mergers, mutual cooperation between companies and new information technology have combined to highlight the role and importance of intangible assets as a key factor in creating value for companies (Lee et al., 2005).

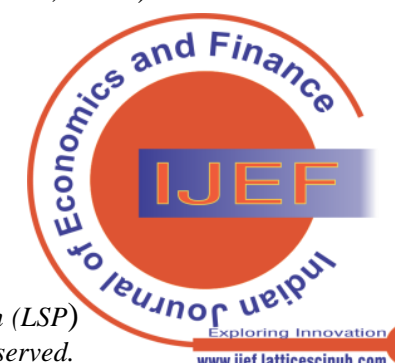


Therefore, the measurement of intangible assets has attracted the interest of accounting researchers, especially because of the growing gap between the book value and the market value of companies. This gap is widening due to a lack of recognition of intangibles factors as assets. The main reason for not recognizing these factors as assets is the existence of a conservative nature in the recognition and characteristics of current accounting standards governing the accounting community. In addition, auditing firms place a lot of pressure on companies to recognize these items due to high uncertainty. These factors have reduced the information content of financial statements and created a gap between the book value and the market value of companies. The current situation in the accounting community has led the International Accounting Standards Board (2007) and the Financial Accounting Standards Board (2001) to try to find ways to measure and identify intangible assets. Both of these standardization boards warn of the need for knowledge-based economic growth, along with increasing the reliability of intangible assets, through the development of information technology. All of this has led many experimental research in accounting to seek to analyze the value relationship between traditional accounting variables in order to evaluate financial information for investors (Pascal et al., 2010).

According to the Financial Accounting Standards Board, if research and development activities are carried out to produce new products and improve old ones or reduce future operating costs, it is expected that the knowledge gained will benefit in future periods. Therefore, this knowledge can be considered as a company's asset or an increase in the total value of the company's current assets. Lamertejan (2006) has divided experimental studies into three categories in terms of the criteria used to measure financial performance:

1- Studies that have used the benchmark ratio of market value to book value to measure financial performance show that in each of the five studies that used these metrics to measure financial performance, there was a positive and significant relationship between social responsibility and financial performance is confirmed.

2- None of the studies that have used the return on assets (ROA) to measure financial performance have reached the conclusion of a negative and significant relationship.

3- Studies to measure financial performance have used market value criteria have been divided into two categories: comparative studies and event studies. Among comparative studies, the results vary considerably, with the majority reporting a mixed or ineffective relationship. Event studies provide a better picture of this relationship because they have compared a company's revenue to that company's own.

Subagnies (1994) found that for every dollar increase in research and development spending, there was a two-dollar increase in net profit. Lu and Subagnies (1996) observed that there was a positive relationship between current operating profit and loss and the extent of research and development costs. Lu (1998) found that there is a positive relationship between stock prices and research and development disclosures. Lakonishuk and Sogianis (2001) argued that in companies with high research and development spending rates, the market value of the company and the persistence of abnormal profits are lower. In a study, Sharad and Zhang (2006) concluded that research and development costs increase the persistence of abnormal profits. Based on this, the first hypothesis of the research is formulated as follows.
H1: Innovation strategy has a positive effect on financial performance.

\section{B. Innovation Strategy and Social Performance}

Social responsibility and spiritual values were considered in the 1960s by pioneers of the concept of strategy. Igor Ansev (1965), in his book Strategy of the Company, implies the effect of non-economic goals on the economic goals of the company. By non-economic goals, he means issues such as philanthropy, the principles of personal morality, social responsibility, social status, and credibility (Mela julienne, 2006). Freeman (1997) considers social responsibility to be a measure taken by a company to significantly affect the level of welfare of its social stakeholder. Macquilieu and Siegel (2001) see social responsibility as measures to improve the well-being of society, beyond the interests of the company and legal requirements. According to the criteria of the Vigo Social Responsibility Institute, social responsibility has the following five dimensions:

1- The working conditions of the social responsibility environment include: continuous improvement of working conditions, evaluation of job skills and staff selection process, improvement of industrial relations and establishing social dialogue between senior management and employees.

2- Dimension of Social Responsibility Company Leadership: Transparency and efficiency of a company's management towards shareholders and other stakeholders.

3- The aspect of society and the local community of social responsibility: it is how the interests of the company are aligned with the interests of the community and the territory in which the company operates.

4- Environmental dimension of social responsibility: The extent of the company's attention to the impact of its operations on environmental pollution; and

5- Behavioral aspects of business in social responsibility: Paying attention to the needs and wants of customers and suppliers is a flexible and transparent attitude towards them (Van De Weld et al., 2005).

Swagianis (1996) found that there is a direct relationship between investment in research and development and performance (in terms of shareholder satisfaction). In their study, Groov and Nguyen (2012) showed that the importance of the variable of real or projected demand for product innovation for customer segments, customer demand, and shareholders is important. Opposing groups that are interested in showing the positive impact of innovation on social performance can use the views of Cigarette and inzektri (2006). They believe that the cost of innovation is risky and dangerous and will cause dissatisfaction among employees. Regarding this theory, it can be said that there is a negative relationship between innovation and social performance. This can be done by modifying the workforce and replacing them with robots. According to this assumption, these robots are financially expensive and are exempt from insurance and taxes until today. According to the literature, the second hypothesis is formulated as follows.

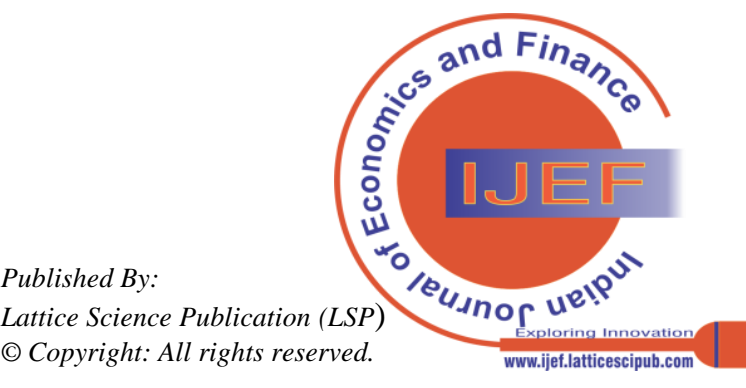


H2: Innovation strategy has a positive effect on social performance.

\section{Innovation Strategy and Environmental Performance}

Environmental performance is the set of operations of a company that is compatible with environmental conditions. This performance is mainly measured by the criteria and scales set by the relevant institutions and agencies, both agricultural and international (Sarompet, 2005). A study by Nakaloo (2005) in Japan found that a company's environmental performance is directly related to a company's financial performance.

Clarcson et al. (2004) have divided previous research into environmental accounting into three broad categories:

(1) Studies that examine the relationship between environmental performance assessment information and environmental performance (environmental disclosure), (2) Studies that examine management decisions to disclose potential environmental commitments, and (3) Studies that have examined the relationship between environmental disclosure and environmental performance. Camp et al. (1994) argued in their research that techniques, processes, can reduce emissions. It is one aspect of using innovation in the company to show the importance of the environment.

Oltra (2008) examined the impact of innovation on the environment. In his opinion, innovation is not only effective for research and development, but also the existence of new technologies. Baker and Cincole (2002), Gomez Magia (2000), Druckch and Lyon (2002) showed that innovation can enable a company to conduct research and development in the face of environmental change in a way that leads to improved performance.

H3: Innovation strategy has a positive effect on environmental performance.

\section{RESEARCH METHODOLOGY}

This study can be considered as applied, descriptive and correlational research. The research approach is post-event (using data from past events). Multivariate regression has been used to test the hypotheses. The companies tested in this study include all companies listed on the Tehran Stock Exchange during the years 2011 to 2018. Sample companies are companies that have the following set of conditions:

Prior to 2011, they were accepted on the Tehran Stock Exchange. The end of their financial year is March 20. Do not change or stop financially during the period under review. Not included in banks and financial institutions (investment companies, financial intermediaries, holding companies, banks, etc.). After applying the restrictions, all the remaining companies, i.e., 129 companies, were examined during 8 years from 2011 to 2018.

The first hypothesis test model: $F P$

$$
\begin{aligned}
& \beta_{s}+\beta_{i} R \& D_{i, t}+\beta_{\tau} S I Z E_{i, t}+\beta_{\tau} A G E_{i, t}+ \\
& \beta_{t} D E B T_{i, t}+\varepsilon_{i, t}
\end{aligned}
$$

The second hypothesis test model:
$S P$

$$
\begin{aligned}
& \beta_{s}+\beta_{i} R \& D_{i, t}+\beta_{\tau} S I Z E_{i, t}+\beta_{\tau} A G E_{i, t}+ \\
& \beta_{q} D E B T_{i, t}+\varepsilon_{i, t}
\end{aligned}
$$

Third Hypothesis Test Model:

$E P=$

$$
\begin{aligned}
& \beta_{s}+\beta_{0} R \& D_{i, t}+\beta_{t} S I Z E_{i, t}+\beta_{\tau} A G E_{i, t}+ \\
& \beta_{\tau} D E B T_{i, t}+\varepsilon_{i, t}
\end{aligned}
$$

\section{A. Independent Variable}

The independent research variable is the company's innovation strategy, which is measured by the company's investment ratio in research and development over total sales. The effect of this type of variable on the company's operations has been long-run due to the nature of its impact and its results can be seen at the end or after the course or financial periods. In this study, according to Miller and Gashbo's (2006), the intensity of investment in the research and development unit on total sales is used to measure this variable.

$\mathrm{R} \& \mathrm{D}=\mathrm{R} \& \mathrm{D}$ costs/total sales

\section{B. The Dependent Variables}

Dependent variables of this research include financial performance, social performance and environmental performance.

\section{1) Financial Performance}

Return on Equity (ROE) are used to measure financial performance based on Brown and Kyler (2004).

$\mathrm{ROE}=$ Net Income/Book value of equity

\section{2) Social Performance}

To calculate this variable, the model used in Pourali and Hejjami's research (2014) has been used. The overall value of disclosure of corporate social responsibility is obtained from the sum of the partial values of the dimensions of corporate social responsibility and can be calculated from the following equation.

$C S R D_{i, t}=E M P D_{i, t}+C O M D_{i, t}+P R O D_{i, t}+E N V D_{i, t}+\varepsilon_{i, t}$ Where,

$C S R D=$ Corporate Social Responsibility Disclosures

$E M P D=$ Employee Relation Disclosure

$C O M D=$ Community Involvement Disclosure

$P R O D=$ Product Disclosure

ENVD $=$ Environment Disclosure

Total score of disclosure of corporate social responsibility: $\operatorname{CSR} D_{i, t}=\frac{\sum_{t=8}^{n} x_{\text {it }}}{n_{\text {i }}}$

Where,

$n_{\mathrm{i}}=$ Estimated number of items for firm's i and period of $\mathrm{t}$

$x_{\text {it }}=$ If the disclosure items are quantitative and detailed in the form of any of the numbers, a detailed description of the activity or images, charts, tables, will be given to that three-disclosure score. If the information is disclosed in a non-quantitative manner, the disclosure score will be two. If the disclosure cases are qualitative and the explanations are in the form of a sentence or paragraph, the disclosure score will be one.

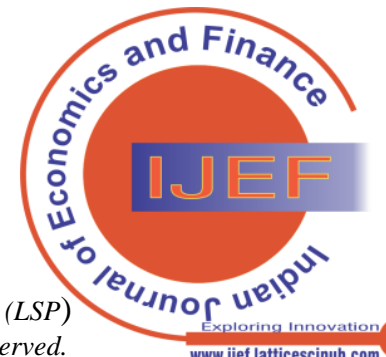


Otherwise, if the disclosure is not made in this case, the disclosure score is zero.

C. Employee information disclosure rate: We need six criteria to show the extent to which information about employee relationships is disclosed:

(1) Employee environmental health, (2) Employee training,

(3) Employee benefits, (4) Employee specifications, (5) Employee share ownership, (6) Employee safety and health (ISO 18000).

The score for disclosing information about employee relationships is calculated as follows.

$E M P D_{i, t}=\frac{\sum A}{1.9}$

Where,

$E M P D=$ Employee Relation Disclosure

$\mathrm{A}=$ Disclosure score for each of the employee relationship criteria for firm $i$ and time $t$;

The number 18 in the denominator indicates six criteria related to the degree of disclosure of employee relations with the maximum score (assuming that companies have disclosed the best cases).

D. Community Involvement Disclosure rate: We need six criteria to show the extent to which social participation information is disclosed: 1) Cash Target Program, 2) Charitable Program, 3) Scholarship Program, 4) Financial Supporters for Sports Activities 5) Supporters of National Pride, 6) Public Projects (ISO 18000). The social participation disclosure score is as follows:

$C O M D_{\text {i. } .5}=\frac{\sum B}{18}$

$C O M D=$ Community Involvement Disclosure rate

$\mathrm{B}=$ Disclosure score for each of the social participation criteria for firm i and time $t$.

The number 18 in the denominator represents six criteria for the degree of disclosure of social participation with the highest score (assuming that the companies have disclosed the best cases).

Production information disclosure rate: To show the disclosure rate of information related to production information disclosure, we need four criteria: 1) product safety, 2) product quality, 3) product development, 4) after-sales service (ISO 9000). The score for the disclosure of production information is as follows:

$P R O D_{\text {i } . t}=\frac{\sum c}{1 T}$

Where,

$P R O D_{\mathrm{i} .5}=$ Production disclosure score in company $\mathrm{i}$ and period t;

$\mathrm{C}=$ Disclosure score for each of the production criteria for company i in period $\mathrm{t}$.

The number 12 in the denominator represents the four criteria for maximizing production disclosure (assuming that companies have disclosed the best practices).

\section{3) Environmental Performance}

To demonstrate the level of environmental information disclosure, we need four criteria: (1) air pollution control, (2) prevention and compensation programs, (3) protection and use of recycled products, (4) environmental rewards (ISO 14000). The environmental exposure score is obtained from the following equation:

$E N V D_{\text {i.t. }}=\frac{\sum D}{1 \pi}$

Where,
$E N V D_{\text {i.t. }}=$ Environmental disclosure score in company i in period $\mathrm{t}$;

$\mathrm{D}=$ Disclosure score for each of the environmental criteria in company i in period $\mathrm{t}$.

The number 12 in the denominator indicates four criteria for the degree of environmental exposure with the highest score (assuming that the companies have disclosed the best cases).

\section{E. Control variables}

Firm debt: According to the research by Kachar and David, 1996; Barker and Muller, 2002; Laab and Oveel, 2003; Kouh, 2003; Jabouri, 2007, to measure the variable of debt of a firm, the total debt is divided by the total assets of the firm.

Firm size variable: Company size can affect a company's financial policies. In fact, large companies invest more in research and development than small and medium-sized companies. In this study, according to Chen et al. (2008), to measure the size of the company, the logarithm of the sum of assets plus the sum of sales divided by the number 2 was used. Firm age variable: To measure this control variable, the logarithm of the number of years of the company's activity is used.

\section{DATA ANALYSIS AND RESEARCH RESULTS}

Descriptive statistics of research variables for sample companies are presented in Table (1), which indicates the amount of descriptive parameters including central indicators such as mean and median. The second category of information includes dispersion parameters such as standard deviation and skewness, which indicate the distribution of data around the mean axis. Since the number of sample companies of 129 companies in 8 years in the range of 2011-2018 has been studied, the number of observations in panel data is 1032 .

Table-1: Descriptive statistics of research variables for sample companies

\begin{tabular}{|c|c|c|c|c|c|c|c|}
\hline variable & R\&D & FP & SP & EP & SIZE & DEBT & AGE \\
\hline Mean & .000 & $\begin{array}{c}.280 \\
0\end{array}$ & $\begin{array}{c}2.28 \\
0\end{array}$ & $\begin{array}{c}.510 \\
0\end{array}$ & $\begin{array}{c}14.35 \\
0\end{array}$ & .5900 & $\begin{array}{c}3.63 \\
0\end{array}$ \\
\hline Median & .000 & $\begin{array}{c}.270 \\
0\end{array}$ & $\begin{array}{c}2.00 \\
0\end{array}$ & $\begin{array}{c}.000 \\
0\end{array}$ & $\begin{array}{c}14.18 \\
0\end{array}$ & .5800 & $\begin{array}{c}3.74 \\
0\end{array}$ \\
\hline $\begin{array}{c}\text { Standard } \\
\text { deviation }\end{array}$ & .010 & $\begin{array}{c}.380 \\
0\end{array}$ & $\begin{array}{c}1.45 \\
0\end{array}$ & $\begin{array}{c}.640 \\
0\end{array}$ & $\begin{array}{c}1.490 \\
0\end{array}$ & .2500 & $\begin{array}{c}.360 \\
0\end{array}$ \\
\hline skewness & 12.2 & -.650 & $\begin{array}{c}.710 \\
0\end{array}$ & .900 & .620 & 2.370 & $\begin{array}{c}. .560 \\
\text { Minimum }\end{array}$ \\
\hline 000 & -3.40 & .000 & .000 & $\begin{array}{c}10.34 \\
0\end{array}$ & .090 & $\begin{array}{c}2.56 \\
0\end{array}$ \\
\hline Maximum & .110 & $\begin{array}{c}2.88 \\
0\end{array}$ & $\begin{array}{c}8.00 \\
0\end{array}$ & $\begin{array}{c}2.00 \\
0\end{array}$ & $\begin{array}{c}19.55 \\
0\end{array}$ & 2.630 & $\begin{array}{c}4.22 \\
0\end{array}$ \\
\hline
\end{tabular}

It can be seen that among the variables, the size of company with a value of 14.350 has the highest average and innovation strategy with a value of 0.000 has the lowest average. Also, the size of the company with a value of 1.49 has a larger standard deviation and a wider range, which indicates that the size of the company is far from the average of most companies. The innovation strategy with a value of 0.01 has a standard deviation and a less wide range.

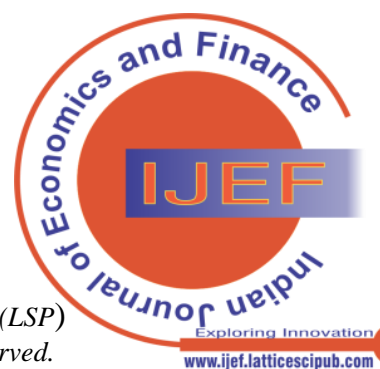




\section{F-Limer Test}

The F-Limer test was used to select each of the Pooled or Panel Model.

In order to evaluate the results of F-Limer, if the probability of the F-statistic is greater than 0.05, the Pooled data method should be used. Summary of the results of the F-Limer test for all models is presented in Table (2).

Table-2: F-Limer test results

\begin{tabular}{|l|l|l|l|}
\hline Model & Statistics & P-Value & result \\
\hline 1 & 2.2545 & .0000 & Panel data \\
\hline 2 & 5.2177 & .0000 & Panel data \\
\hline 3 & 5.003 & .0000 & Panel data \\
\hline
\end{tabular}

\section{Hausman test}

The Hausman test is used to select between random or fixed effects model. The results of the Hausman test for research models are as follows:

Table (3) - The results of the Hausman test for choosing between a fixed or random effects

\begin{tabular}{|l|l|l|l|}
\hline Model & $X^{\text {s }}$ Statistics & P-Value & result \\
\hline 1 & 32.5143 & .0000 & $\begin{array}{l}\text { Fixed effects model } \\
\text { is appropriate }\end{array}$ \\
\hline 2 & 63.9436 & .0000 & $\begin{array}{l}\text { Fixed effects model } \\
\text { is appropriate }\end{array}$ \\
\hline 3 & 11.5209 & .0213 & $\begin{array}{l}\text { Fixed effects model } \\
\text { is appropriate }\end{array}$ \\
\hline
\end{tabular}

The results of Table (3) indicate that the fixed effects method should be used in all models.

\section{Homoscedasticity test}

One of the basic assumptions of a proper regression model is the homoscedasticity. To test this assumption, the Breush-Pagan-Godfrey test was used. The results of this test are summarized for all models in Table (4).

Table (4) - Breush-Pagan-Godfrey test result

\begin{tabular}{|l|l|l|l|}
\hline $\begin{array}{l}\text { Mode } \\
1\end{array}$ & Statistics & P-Value & result \\
\hline 1 & 9.6926 & .0000 & Heteroscedasticity \\
\hline 2 & 2.7233 & .0284 & Heteroscedasticity \\
\hline 3 & 3.8043 & .0045 & Heteroscedasticity \\
\hline
\end{tabular}

According to the results of Table (4), the P-value obtained for the Breush-Pagan-Godfrey test for three hypotheses is less than the 0.05, so it can be concluded that in all three models there is a heteroscedasticity. To solve the heteroscedasticity, the generalized least squares (GLS) method was used to estimate the model.

\section{Collinearity test}

A VIF test was used to investigate the existence of a collinearity between the independent variables. If the VIF statistic for the variables is less than 10 , there will be no collinearity between the explanatory variables. Tables (5), (6) and (7) summarize the results of this test.

Table (5)- VIF-test results for first hypothesis

\begin{tabular}{|l|l|l|l|}
\hline variable & VIF-statistic & $1 /$ VIF & Result \\
\hline R\&D & 1.051439 & .951086 & $\begin{array}{l}\text { There is no } \\
\text { collinearity problem }\end{array}$ \\
\hline SIZE & 1.032288 & .968729 & $\begin{array}{l}\text { There is no } \\
\text { collinearity problem }\end{array}$ \\
\hline AGE & 1.015751 & .984494 & There is no \\
\hline
\end{tabular}

collinearity problem There is no collinearity problem

\begin{tabular}{|l|l|l|l|}
\hline Mean VIF & 1.0375 & & \\
\hline \multicolumn{3}{|c|}{ Table (6)- VIF-test results for second hypothesis } \\
\hline variable & VIF-statistic & $1 /$ VIF & Result \\
\hline R\&D & 1.051439 & .951086 & $\begin{array}{l}\text { There is no } \\
\text { collinearity problem }\end{array}$ \\
\hline SIZE & 1.032288 & .968729 & $\begin{array}{l}\text { There is no } \\
\text { collinearity problem }\end{array}$ \\
\hline AGE & 1.015751 & .984494 & $\begin{array}{l}\text { There is no } \\
\text { collinearity problem }\end{array}$ \\
\hline DEBT & 1.050939 & .951538 & $\begin{array}{l}\text { There is no } \\
\text { collinearity problem }\end{array}$ \\
\hline Mean VIF & 1.0375 & & \\
\hline
\end{tabular}

Table (7)- VIF-test results for third hypothesis

\begin{tabular}{|l|l|l|l|}
\hline variable & VIF-statistic & $1 /$ VIF & Result \\
\hline R\&D & 1.051439 & .951086 & $\begin{array}{l}\text { There is no } \\
\text { collinearity problem }\end{array}$ \\
\hline SIZE & 1.032288 & .968729 & $\begin{array}{l}\text { There is no } \\
\text { collinearity problem }\end{array}$ \\
\hline AGE & 1.015751 & .984494 & $\begin{array}{l}\text { There is no } \\
\text { collinearity problem }\end{array}$ \\
\hline DEBT & 1.050939 & .951538 & $\begin{array}{l}\text { There is no } \\
\text { collinearity problem }\end{array}$ \\
\hline Mean VIF & 1.0375 & & \\
\hline
\end{tabular}

\section{Stationary test of research variables}

Levin, Lin and Chu test was used to determine the reliability of the research variables. The results of this test are in the form of Table (8).

\section{Table (8)- Levin, Lin and Chu test result}

\begin{tabular}{|l|l|l|}
\hline & statistic & P-value \\
\hline Levin, Lin and Chu test & -30.1950 & .0000 \\
\hline Im, Pesaran and Shin test & -35.1379 & .0000 \\
\hline
\end{tabular}

The results of the unit root test show that the variables are stationary position.

\section{The first hypothesis test}

The results of fitting the first hypothesis model are presented in Table (9).

Table (9)- The results of data analysis in the first hypothesis test

\begin{tabular}{|l|l|l|l|l|}
\hline Variables & coefficient & Std. Error & t-statistic & Prob. \\
\hline C & 2.381383 & .310451 & 7.670628 & .0000 \\
\hline R\&D & -2.587219 & 1.644887 & -1.572886 & .1162 \\
\hline SIZE & .236902 & .021316 & 11.11408 & .0000 \\
\hline AGE & -1.480894 & .123012 & -12.03865 & .0000 \\
\hline DEBT & -.213602 & .048841 & -4.373429 & .0000 \\
\hline AR(1) & .336776 & .035771 & 9.414785 & .0000 \\
\hline $\begin{array}{l}\text { R-square } \\
\text { d }\end{array}$ & $\begin{array}{l}\text { Adj. } \\
\text { R-squared }\end{array}$ & F-statistic & $\begin{array}{l}\text { Prob. } \\
\text { (F-statistic) }\end{array}$ & $\begin{array}{l}\text { Durbin-Watso } \\
\text { n Stat. }\end{array}$ \\
\hline .8064 & .7727 & 23.9936 & .0000 & 1.9870 \\
\hline
\end{tabular}

Given the value of the probability obtained for the $\mathrm{F}$ statistic, which is less than 0.05 , the $\mathrm{H} 0$ hypothesis is rejected, indicating that not all regression coefficients are simultaneously zero. Therefore, at the 95\% confidence level, this model is significant.

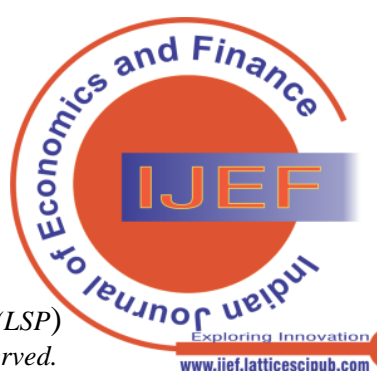


The R-squared of the model is equal to 0.8064, which shows that $80.65 \%$ of the changes in the dependent variable (financial performance) have been described by the independent and control variables.

The variable coefficient of the innovation strategy is 2.5872, which is negative, and the probability of t-statistics for the innovation strategy is 0.1162 . It can be seen that the innovation strategy has a negative effect on financial performance but is not significant. As a result, the first hypothesis of the research is rejected at the $95 \%$ confidence level.

According to the above table, the coefficient of control of the size of the company, which is positive, and the P-value for the size of the company is 0.0000 .

Therefore, the size of the company has a positive and significant effect on financial performance. It is also clear that the age of the company has a significant negative relationship with financial performance. The company's debt also has a negative and significant effect on financial performance. The Durbin-Watson statistic between 1.5 and 2.5 indicates the absence of residual autocorrelation.

\section{The second hypothesis test}

The results of fitting the second hypothesis model are presented in Table (10).

Table (10)- The results of data analysis in the second hypothesis test

\begin{tabular}{|l|l|l|l|l|}
\hline Variables & $\begin{array}{l}\text { coefficien } \\
\mathrm{t}\end{array}$ & Std. Error & t-statistic & Prob. \\
\hline C & -21.11124 & 2.789619 & -7.567786 & .0000 \\
\hline R\&D & -10.68477 & 5.648157 & -1.891727 & .0589 \\
\hline SIZE & .261189 & .123433 & 2.116035 & .0347 \\
\hline AGE & 5.299518 & .940648 & 5.633904 & .0000 \\
\hline DEBT & .601405 & .238959 & 2.516774 & .0121 \\
\hline AR(1) & .451201 & .032923 & 13.70458 & .0000 \\
\hline $\begin{array}{l}\text { R-square } \\
\text { d }\end{array}$ & $\begin{array}{l}\text { Adj. } \\
\text { R-squared }\end{array}$ & $\begin{array}{l}\text { F-statisti } \\
\text { c }\end{array}$ & $\begin{array}{l}\text { Prob. } \\
\text { (F-statistic }\end{array}$ & $\begin{array}{l}\text { Durbin-Watso } \\
\text { n Stat. }\end{array}$ \\
\hline .6878 & .6336 & 12.6925 & .0000 & 2.1442 \\
\hline
\end{tabular}

According to Table (10), the coefficient of the innovation strategy is 10.68477 , which is negative, and the P-value for the innovation strategy is 0.0589 . As a result, the second research hypothesis is accepted at the $90 \%$ confidence level. All three control variables are also significant.

\section{The third hypothesis test}

The results of fitting the third hypothesis model are presented in Table (11).

Table (11) - The results of data analysis in the third hypothesis test

\begin{tabular}{|l|l|l|l|l|}
\hline Variables & $\begin{array}{l}\text { coefficien } \\
\mathrm{t}\end{array}$ & Std. Error & t-statistic & Prob. \\
\hline $\mathrm{C}$ & .469859 & .262310 & 1.791236 & .0737 \\
\hline R\&D & .783446 & 1.195301 & .655438 & .5124 \\
\hline SIZE & .000304 & .014006 & .021732 & .9827 \\
\hline AGE & .018431 & .073984 & .249122 & .8033 \\
\hline DEBT & .022915 & .031058 & .737809 & .4609 \\
\hline AR(1) & .486253 & .033435 & 14.54312 & .0000 \\
\hline $\begin{array}{l}\text { R-square } \\
\text { d }\end{array}$ & $\begin{array}{l}\text { Adj. } \\
\text { R-squared }\end{array}$ & $\begin{array}{l}\text { F-statisti } \\
\text { c }\end{array}$ & $\begin{array}{l}\text { Prob. } \\
\text { (F-statistic }\end{array}$ & $\begin{array}{l}\text { Durbin-Watso } \\
\text { n Stat. }\end{array}$ \\
\hline .7896 & .7878 & 552.1624 & .0000 & 2.0838 \\
\hline
\end{tabular}

According to Table (11), the innovation strategy has a positive effect on environmental performance but is not significant. As a result, the third hypothesis of the research is rejected at the $95 \%$ confidence level.

\section{CONCLUSION}

This study examines the effect of innovation on the financial, social and environmental performance of companies listed on the TSE. The first hypothesis, which was based on the positive relationship between innovation and environmental performance, according to statistical tests, did not prove its positive effect and significant effect on financial performance, and the first hypothesis was not accepted. This result is consistent with a Beroni's study (2005) that studied a Spanish sample. He found that investing in the R\&D unit has a negative but insignificant effect on the company's financial performance. The results of the statistical test of this second hypothesis show a positive and significant relationship between innovation and social performance of the organization according to the concepts and dimensions examined from the concept of social responsibility. This means that investing in the company's R\&D unit can improve the company's social performance.

The third hypothesis focused on the relationship between innovation strategy and the company's environmental performance. In general, it can be inferred that innovation tools can be used to improve and grow the company's financial and environmental performance. In fact, addressing the style and model of investing in research and development will innovate and improve financial, social and environmental performance.

\section{REFERENCES}

1. Oltra, V. (2008). Variety of technological trajectories in low emission vehicles (LEVs): Apatent data analysis. Journal of Cleaner Production, 3, 534. [CrossRef]

2. Schroll, A., \& Mild, A. (2011). Open innovation modes and the role of internal R\&D. An empirical study on open innovation adoption in Europe. European Journal of Innovation Management, 14(4), 475-495.

3. Hall, B. H. (2000). Innovation and market value. In R. Barrell, G. Mason, \& M. O'Mahoney (Eds.), Productivity, innovation and economic performance (pp. 177-198). Cambridge, UK: Cambridge University, Press.

4. Freeman, R. E. (1984). Strategic management: Astakeholder approach. Boston: Pitman. Développement, Croissance et Progrès, 36(1), 213-229.

5. Lee, P. G., \& O’Neil, H. M. (2003). Ownership structures and R\&D investments of U.S. and Japanese firms: Agency and stewardship perspectives. Academy of Management Journal, 46(2), 212-225. [CrossRef]

6. Sougiannis, T. (1994). The accounting based valuation of corporate R\&D. The Accounting Review, 69(1), 44-68.

7. Sumeonidis, G. (1996). Innovation, firm size and market structure: Schumpeterian hypotheses and some new themes. Journal of Financial Economics, 37, 69-65

8. Baker, W. E., \& Sinkula, J. M. (2002). Market orientation, learning orientation and product innovation: Delving into the organization's black box. Market Focus Manage; 5(1), 5-23

9. Kochhar, R., \& David, P. (1996). Institutional investors and firm innovation: A test of competing hypotheses. Strategic Management Journal, 17(1), 73-84. [CrossRef] 
10. Barker, V. L., \& Mueller, G. C. (2002). CEO characteristic and firm R\&D spending. Management Science, 48(1), 782-801. [CrossRef]

11. Koh, P. S. (2003). On the association between institutional ownership and aggressive corporate earnings management in Australia. The British Accounting Review., 35, 105-128[CrossRef]

12. Chen, H. L., Hsu, W. T. and Huang, Y. S. (2008). Top management team characteristics, R\&D investment and capital structure in the IT industry. Small Business Economics. Available at http://www.springerlink.com/index/k062471w88846740.pdf

13. Pourali, Mohammad Reza and Hejjami, Mohadeseh (2014), Brazilian Advertising for Disclosure of Social Counseling and Possible Nadi in Different Companies Purchased in the Tehran Stock Exchange, Quarterly Journal of Specialized and Management Research, No. 10.

14. Börjesson, S., \& Löfsten, H. (2012). Capabilities for innovation in small firms - A studyof 131 high-tech firms and their relation to performance. International Journalof Business Innovation and Research, 6(2), 149-176. [CrossRef]

15. Kemp, R., Miles I. and Smith, K. (1994). Technology and the transition to environ-mental stability. Continuity and change in complex technology systems. Finalreport from project technological Paradigms and Energy Technologies.for SEERresearch programme of the CEC. (DG XII).

\section{AUTHORS PROFILE}

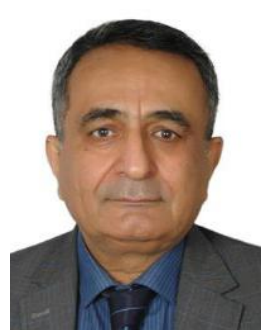

Dr. H.Saremi, Assrar higher Institute of Education-Amozgar-68 Blvd., Mashad-KhorasanRazavi, Iran. E-mail: saremi@asrar.ac.ir, hadi_sarem@yahoo.com

\section{Education:}

Ph. D. Commerce (Financial Management)

M. Com -Commerce (Cost Accounting)

B. A- Art (Statistics)

B. Com- Commerce (Finance)

Research Interest :

- Financial Management

- Human Resources Management

- Cost Accounting

- Finance

Executive Experience :

-Internal Auditing of Iran National Oil Company of Iran: 1988-1990.

-Head \&Faculty Member of Accounting Dep. Azad Islamic University of Brigand-Iran (1990-1991)

-Vice chancellor in Administrative\& Financial Affairs of Azad Islamic University of Iran-Brigand Branch (1990-1997).

- Vice chancellor in Administrative\& Financial Affairs \& Faculty Member of Azad Islamic University of Iran Torbat-e-Jum Branch (1997- 2002).

•Vice- Chancellor in Administrative\& Financial Affairs of Azad Islamic University of Iran- Quchan branch (2011 till 2019)

-Head of Professional Administrative and Financial Council of Khorasan Razavi Province-Iran-2o14-219

- Member of Financial\& Administrative Committee of Islamic Azad Universities of Khorasan (State) District (1997-2001.(

-Chairman of the Board of Directors of Bilan Karan Sahrgh Auditing Institute-1992-1996

-Financial Consulate, Aida cabale Industry Mashhad-Iran. (2000)

-Financial Consulate, Sabon Tala Chemical Industry Mashed-Iran (1997) - Secretary of Management Association of Iran-Khorasan Branch (20012005 ).

-Principal of Management Studies Center (under supervision of Applied and Science University of Iran Mashed-Iran (2004-2005).

-Member of Board of Directors Management Association of Iran-khorsan Branch.(2002-2014).

•Custodianship of sarem charity Institution (2002-2016)

-Present Situation :Precisdent (Chancellor) of Asrar Higher Eduction Institute-Mashad-Iran(from 2019 till date)

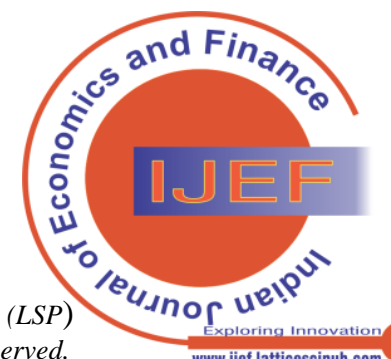

